\title{
As tecnologias da reprodução: discursos sobre maternidade e paternidade no campo da reprodução assistida no Brasil
}

Fernanda Bittencourt Vieira

Curso: Doutorado em Sociologia

Data da defesa: 15 de agosto de 2008

Orientadora: Prof ${ }^{\mathrm{a}}$. Dr ${ }^{\mathrm{a}}$. Lourdes Maria Bandeira

\section{Resumo}

A reprodução assistida tornou possível o início do processo reprodutivo fora do corpo. A manipulação e circulação de embriões, de óvulos, de sêmen e o "deslocamento" do útero, com a chamada gestação de substituição, permitiram novas experiências sociais. Este trabalho investiga os discursos dos principais atores e atrizes sociais, no campo da reprodução assistida no Brasil, sobre questões suscitadas por essas inovações tecnológicas em relação à "parentalidade". Nesse campo, novas tecnologias reprodutivas, futuros pais e mães, médicos(as), legisladores(as), feministas, bioeticistas, entre outros atores e atrizes sociais, confrontaram-se em torno de células reprodutivas, embriões congelados - possíveis filhos(as) relacionados(as) geneticamente ou não aos seus pais -, criando ou reatualizando discursos sobre maternidade, paternidade, reprodução, direitos individuais, direitos parentais e direitos sexuais e reprodutivos, ancorados em visões determinadas sobre 
as relações de gênero, classe e sexualidade. Tais discursos são também observados como uma forma de subjetivação gerada por inovações científicas que compreendem novas fronteiras morais. A perspectiva teórica é originária do encontro de tradições sociológicas com a teoria feminista. A pesquisa foi baseada em levantamento documental sobre os debates legislativos em torno da regulação da reprodução assistida e em um grupo de discussão virtual sobre infertilidade. As fontes de análise, plurais, perfazem um mosaico através do qual se vislumbram vozes e dilemas, relacionados aos ideais sociais de família no país. A tese identifica tensões e conflitos entre os aspectos de continuidade e ruptura, normalização e subversão, invenção e reprodução, autonomia e assujeitamento. Os discursos sobre maternidade e paternidade são reinventados, reatualizados e reinscritos em uma sociedade de "risco fabricado" em que as hierarquias reprodutivas se impõem.

Palavras-chave: reprodução assistida; novas tecnologias reprodutivas; feminismo; gênero; sexualidade; maternidade; paternidade; hierarquias reprodutivas. 